\title{
How Can Teleostean Inner Ear Hair Cells Maintain the Proper Association with the Accreting Otolith?
}

\author{
JEN-CHIEH SHIAO, ${ }^{1}$ LI-YIH LIN,${ }^{2}$ JIUN-LIN HORNG,${ }^{1}$ PUNG-PUNG HWANG,,${ }^{1 *}$ \\ AND TOYOJI KANEKO ${ }^{3}$ \\ ${ }^{1}$ Institute of Zoology, Academia Sinica, Taipei 11529, Taiwan \\ ${ }^{2}$ Department of Physical Therapy, Shu-Zen College of Medicine and Management, \\ 821 Kaohsiung, Taiwan \\ ${ }^{3}$ Department of Aquatic Bioscience, Graduate School of Agricultural and Life Sciences, \\ University of Tokyo, 113-8657 Tokyo Japan
}

\begin{abstract}
The perception of equilibrium and sound in fish depends on the deflection of hair bundles of hair cell by the otolith. However, the accreting nature of teleostean otoliths poses a problem for maintenance of proper contact between the hair bundle and the otolith surface. Immunocytochemical staining localizes abundant proton-secreting $\mathrm{H}^{+}$-ATPase in the apical membrane of the hair cells. The $\mathrm{H}^{+}$-ATPase-mediated proton secretion into the endolymph causes an approximately 0.4 -unit $\mathrm{pH}$ decrease, which was quantified by an $\mathrm{H}^{+}$-selective microelectrode. Thus, the hair cells maintain the proper distance from the otolith by neutralizing the alkaline endolymph to retard $\mathrm{CaCO}_{3}$ deposition on the otolith opposite the sensory macula. Carbonic anhydrase, which hydrolyses $\mathrm{CO}_{2}$ and produces $\mathrm{HCO}_{3}{ }^{-}$and $\mathrm{H}^{+}$, was also localized in the hair cells. Ionocytes showed prominent immunostaining of carbonic anhydrase and $\mathrm{Na}^{+}-\mathrm{K}^{+}$-ATPase, indicating its role in transepithelial transport of $\mathrm{HCO}_{3}{ }^{-}$across the membranous labyrinth into the endolymph. Ionocytes form a ring closely surrounding the sensory macula. $\mathrm{HCO}_{3}{ }^{-}$secreted from the ionocytes may serve as a barrier to neutralize $\mathrm{H}^{+}$diffused from the sensory macula while keeping the endolymph alkaline outside the sensory macula. The ingenious arrangement of ionocytes and hair cells results in a unique sculptured groove, which is a common feature on the proximal surface of all teleostean otoliths. J. Comp. Neurol. 488:331-341, 2005. ๑ 2005 Wiley-Liss, Inc.
\end{abstract}

Indexing terms: labyrinth; auditory system; $\mathrm{H}^{+}$-ATPase; $\mathrm{H}^{+}$-selective microelectrode; hearing; vestibule

The sense of equilibrium depends on mechanosensory hair cells, which detect the acceleration and tilt of the head relative to gravity (Hudspeth, 1989). Hair cells possess hair bundles consisting of many stereocilia and a kinocilium protruding into the endolymph-filled membranous labyrinth. In the mammalian vestibular apparatus, the hair bundle is embedded within a gelatinous otoconial membrane that contains thousands of microscopic otoconia, averaging $10 \mu \mathrm{m}$ in length (Lim, 1984). Relative motion between the hair cell and the otoconial membrane results in deflection of the hair bundle and initiates a nerve impulse that is transmitted to the vestibulocochlear nerve (Hudspeth, 1989).

The teleostean inner ear differs structurally from that of mammals. Mammals have two otolith organs, the utricle and the saccule, whereas teleosts have an additional oto- lith organ, the lagena. Furthermore, the hair bundles of teleostean inner ear hair cells directly contact the otolith surface (Schellart and Wubbels, 1998). Moreover, the size and morphology of mammalian otoconia are stable after the individual matures, but the teleostean otolith grows

Grant sponsor: National Science Council of Republic of China; Grant number: NSC 92-2811-B-001-068.

The first two authors contributed equally to this work.

*Correspondence to: Pung-Pung Hwang, Institute of Zoology, Academia Sinica, No. 128, Sec. 2, Academia Rd., Nankang, Taipei, Taiwan, Republic of China 11529. E-mail: pphwang@gate.sinica.edu.tw

Received 6 September 2004; Revised 30 November 2004; Accepted 17 February 2005

DOI 10.1002/cne.20578

Published online in Wiley InterScience (www.interscience.wiley.com). 
continually throughout a fish's life (Campana and Neilson, 1985). However, an accreting otolith takes more and more space, posing a problem for maintenance of the proper contact between hair cells and otoliths. Without a protective mechanism, the growing otolith would eventually crush the hair cells, impairing equilibrium and hearing functions. It is not clear how the hair cells can simultaneously maintain close contact with the otolith and avoid being compressed by the accreting otolith onto the bony auditory capsule. All teleostean otoliths grow much more slowly at the sulcus, a sculptured groove along the medial face of the proximal surface of the otolith (Dunkelberger et al., 1980). Facing the sulcus is the sensory macula, which contains numerous hair cells. This suggests that the hair cells can somehow regulate otolith growth to keep the proper association with the otolith surface.

The teleostean otolith grows by adding mainly $\mathrm{CaCO}_{3}$ and a few protein fibers to the otolith surface in a daily cycle (Pannella, 1971; Campana and Neilson, 1985). In teleosts, the alkaline endolymph favors the combination of $\mathrm{Ca}^{2+}$ and $\mathrm{HCO}_{3}{ }^{-}$to form $\mathrm{CaCO}_{3}$ (Payan et al., 1997). Thus, we hypothesize that the hair cell may retard $\mathrm{CaCO}_{3}$ biomineralization by acidifying the regional endolymph near the sensory macula. Acidification of the intra- and extracellular compartment is usually carried out by proton-secreting ion transporters in specialized cells (Brown and Breton, 1996). In this study, we localize the vacuolar $\mathrm{H}^{+}$-ATPase in the apical membrane of hair cells by immunocytochemical staining. $\mathrm{H}^{+}$activity $(\mathrm{pH})$ mediated by $\mathrm{H}^{+}$-ATPase at apical sides of the hair cell was evaluated by $\mathrm{H}^{+}$-selective microelectrode technique.

\section{MATERIALS AND METHODS Labyrinth extraction}

Adult zebrafish, Danio rerio, approximately $0.2 \mathrm{~g}$ in wet weight and $3 \mathrm{~cm}$ in total length, were obtained from laboratory stock. All fish handling complied with the protocol of "Animal care and utilization of Academia Sinica" for experiments on animals. Fish were maintained at a density of three to six individuals per liter at $26-29^{\circ} \mathrm{C}, \mathrm{pH} 7.7$. To obtain the inner ear tissue, fish were anesthetized with $0.1 \mathrm{mg} \mathrm{ml}^{-1}$ MS 222 solution (3-aminobenzoic acid ethyl ester; Sigma, St. Louis, MO), then decapitated, and their skulls were opened with small scissors under a stereomicroscope. The brain was removed forward to expose the otoliths. The posterior cranium containing the bony auditory capsules was cut off and placed in a petri dish containing phosphate-buffered saline (PBS). The lagena and saccule containing the otoliths were extracted by forceps from the bony capsules. The process from decapitation to lagena and saccule removal was completed within 5 minutes. The extracted lagena and saccule were used for immunocytochemical staining and immunoblotting. At least 100 fish were examined for the presence of $\mathrm{Na}^{+}-\mathrm{K}^{+}$. ATPase, carbonic anhydrase, and $\mathrm{H}^{+}$-ATPase in the lagenar and saccular epithelial cells.

\section{Antibodies}

Antibodies against $\mathrm{Na}^{+}-\mathrm{K}^{+}$-ATPase, carbonic anhydrase and $\mathrm{H}^{+}$-ATPase were used as the primary antibodies. Mouse anti-chicken $\mathrm{Na}^{+}-\mathrm{K}^{+}$-ATPase $\alpha$-subunit monoclonal antibody was purchased from the Developmental Studies Hybridoma Bank, Iowa University. Rabbit anti- flounder gill carbonic anhydrase polyclonal antibody was provided by Sender et al. (1999). The polyclonal antibody against the $\mathrm{H}^{+}$-ATPase was raised against the $\alpha$-subunit of killifish $\mathrm{H}^{+}$-ATPase (Katoh et al., 2003). The secondary antibody for immunofluorescent staining was fluorescein isothiocyanate (FITC)- or Cy5-conjugated goat anti-rabbit IgG and Texas red- or FITC-conjugated goat anti-mouse IgG (Jackson Immunoresearch, West Grove, PA). TRITCconjugated phalloidin (Sigma) was used to stain the actinrich hair bundle of the hair cells. The secondary antibody for immunoblotting was alkaline phosphatase-conjugated goat anti-mouse or goat anti-rabbit IgG (Jackson Immunoresearch).

\section{Immunofluorescent staining}

Extracted lagena and saccules were immediately fixed in $4 \%$ paraformaldehyde in $0.1 \mathrm{M}$ phosphate buffer (PB; $\mathrm{pH}$ 7.4) for approximately 20 minutes at $4^{\circ} \mathrm{C}$. After being washed in PBS for 10 minutes, fixed tissues were treated with $100 \%$ ethanol for 10 minutes at $-20^{\circ} \mathrm{C}$ and washed again in PBS. Tissues were immersed in $3 \%$ bovine serum albumin (BSA) at room temperature for 30 minutes to block nonspecific binding, then incubated in PBS-diluted primary antibody (1:100-1:500) for 2 hours at room temperature or overnight at $4^{\circ} \mathrm{C}$. To label the hair bundle, lagena and saccules were incubated in $30 \mathrm{nM}$ TRITCconjugated phalloidin solution for 5 minutes at room temperature. Samples were washed in PBS for 10 minutes twice and incubated with PBS diluted secondary antibody (1:100) for 1 hour at room temperature. Images were acquired with a confocal laser scanning microscope after washing twice in PBS for 10 minutes. Control tissues were processed in parallel without a primary antibody. Some otolith chambers were fixed and stained without removing otoliths so that all the epithelial cell types could be observed in their original position relative to the otolith.

\section{Confocal laser scanning microscope}

Stained lagena and saccules were observed with a Leica TCS NT confocal laser scanning microscope equipped with an argon laser (488 and $514 \mathrm{~nm}$ ) for excitation, with a Leica DMRE microscope attached. The stained images of $\mathrm{Na}^{+}-\mathrm{K}^{+}$-ATPase, carbonic anhydrase, and $\mathrm{H}^{+}$-ATPase were obtained with the use of a FITC/Texas red/Cy5 filter set, and stained images of actin were obtained with a TRITC filter set controlled by Leica TSC NT software. With the filter set, the emission wavelengths of TRITCconjugated phalloidin or FITC-, Texas red-, or Cy5conjugated antibodies were separated and transmitted to different photomultipliers. The images from each photo multiplier were subsequently merged to visualize the labels simultaneously.

\section{Immunoblotting}

The membranous labyrinths were collected and pooled from 50 zebrafish. Approximately 15-30 $\mu \mathrm{g}$ of labyrinth protein was heated at $37^{\circ} \mathrm{C}$ (for $\mathrm{Na}^{+}-\mathrm{K}^{+}$-ATPase) for 10 minutes or $95^{\circ} \mathrm{C}$ (for carbonic anhydrase and $\mathrm{H}^{+}$-ATPase) for 3 minutes and fractionated with prestained molecular weight standards (Bio-Rad) and mouse kidney (positive control) by electrophoresis on sodium dodecyl sulfate (SDS)-containing 8\% polyacrylamide gels. Separated proteins were transferred from unstained gels to polyvinylidene difluoride membranes (PVDF-Plus; MSI) by using a tank transfer system (Electrotransfer, TE22; Hoefer). 
Blots were preincubated for 30 minutes in PBST buffer [137 mM NaCl, $3 \mathrm{mM} \mathrm{KCl,} 10 \mathrm{mM} \mathrm{Na} \mathrm{HPO}_{4}, 2 \mathrm{mM}$ $\mathrm{KH}_{2} \mathrm{PO}_{4}, 0.2 \%(\mathrm{v} / \mathrm{v})$, Tween $20, \mathrm{pH}$ 7.4] containing $5 \%$ $(\mathrm{wt} / \mathrm{v})$ nonfat dried milk to minimize nonspecific binding, then incubated overnight with the same primary antibody used in the immunofluorescent staining diluted in PBST (1:5,000). The blot was washed in PBST, followed by 1 hour of incubation with secondary antibody diluted $\times 4,000$ in PBST. Blots were visualized after incubation with $0.015 \%$ nitroblue tetrazolium and $0.07 \%$ bromochloroindolyl phosphate in a reaction buffer (100 mM Tris, $100 \mathrm{mM} \mathrm{NaCl}, 5 \mathrm{mM} \mathrm{MgCl}_{2}$, pH 9.5).

\section{$\mathrm{H}^{+}$-selective microelectrode technique}

An $\mathrm{H}^{+}$-selective microelectrode technique was used to measure $\mathrm{H}^{+}$activity $(\mathrm{pH})$ at apical sides of the hair cell. Microelectrodes with a tip diameter of 3-4 $\mu \mathrm{m}$ were pulled from glass capillary tubes (World Precision Instruments, Sarasota, FL; TW 150-4, with 1.12 and $1.5 \mathrm{~mm}$ inner and outer diameters, respectively) by using a Sutter P-97 Flaming Brown pipette puller (Sutter Instruments, San Rafael, CA). These were then baked in covered dishes at $200^{\circ} \mathrm{C}$ overnight and the covers were removed before further baking at $200^{\circ} \mathrm{C}$ for at least 1 hour.

Microelectrodes were constructed as follows. The capillaries were back-filled with a $1 \mathrm{~cm}$ column of $100 \mathrm{mM}$ $\mathrm{KCl} / \mathrm{H}_{2} \mathrm{PO}_{4}(\mathrm{pH} 7.0)$ and then front loaded with a 20 $30-\mu \mathrm{m}$ column of liquid ion exchanger (LIX) cocktail (Hydrogen Ionophore I-cocktail B; Fluka). The $\mathrm{H}^{+}$-selective microelectrode connected with an operational amplifier (IP Amp, Ion Polarographic Amplifier; Applicable Electronics, East Falmouth, MA) via an $\mathrm{Ag} / \mathrm{AgCl}$ wire electrode holder (World Precision Instruments), and the circuit was completed by placing a salt bridge (3 M potassium acetate, $10 \mathrm{mM} \mathrm{KCl}$, in $3 \%$ agarose connected to a $\mathrm{Ag} / \mathrm{AgCl}$ wire).

Microelectrode positioning was achieved with a stepper motor-driven three-dimensional (3D) positioner (Applicable Electronics). Data acquisition, preliminary processing, and control of the $3 \mathrm{D}$ electrode positioner were performed with ASET software (Science Wares, East Falmouth, MA). The electrode system was attached to an Olympus upright microscope (BX-50WI; Olympus, Tokyo, Japan). A $\times 10$ dry and a $\times 40$ (working distance $3.3 \mathrm{~mm}$ ) waterimmersion objective lens under a differential interference contrast (DIC) device were used. The microscope equipped with a CCD camera allowed images to be visualized on a color monitor and recorded with frame grabber and ASET software. The entire assembly on a 1/4-inch steel plate was located inside a Faraday cage suspended on an air table for vibration suppression.

Prior to the collection of biological data, the microelectrodes were calibrated with standard solutions $(\mathrm{pH} 6,7$, and 8). The Nernstian property of each electrode was measured by placing the electrode in a series of standard $\mathrm{pH}$ solutions ( $\mathrm{pH} 6,7$, and 8). By plotting the voltage output of the probe against $\log \mathrm{H}^{+}$activity, a linear regression yielded a Nernstian slope of $57.8 \pm 2.3(\mathrm{n}=10)$.

\section{Chemicals}

When we measued the proton activity at the apical side of the hair cells, the lagenar chamber was open to remove otolith (asteriscus) and was immersed in modified Ringer solution as follows: $115 \mathrm{mmol} \mathrm{l}^{-1} \mathrm{NaCl}, 30 \mathrm{mmol} \mathrm{l}^{-1} \mathrm{KCl}$, $0.5 \mathrm{mmol} \mathrm{l}^{-1} \mathrm{MgCl}_{2}, 0.5 \mathrm{mmol} \mathrm{l}^{-1} \mathrm{NaH}_{2} \mathrm{PO}_{4}, 0.5 \mathrm{mmol} \mathrm{l}{ }^{-1}$
$\mathrm{KH}_{2} \mathrm{PO}_{4}, 1 \mathrm{mmol} \mathrm{l} \mathrm{l}^{-1} \mathrm{CaCl}_{2}$, buffered with $1 \mathrm{mmol} \mathrm{l} \mathrm{l}^{-1}$ $\mathrm{NaHCO}_{3}$. The $\mathrm{pH}$ value was adjusted to approximately 8.0. The solution also contained freshly added glucose $(1 \mathrm{~g}$ $\mathrm{l}^{-1}$ ) and was aerated before use. The vacuolar $\mathrm{H}^{+}$-ATPasemediated proton secretion was evaluated via N-ethylmaleimide (NEM; Sigma), which was added to the Ringer solution to make final concentrations of $0.1,0.01$, and $0.001 \mathrm{mM}$.

\section{Observation of otolith topology and daily growth increments}

To observe the otolith topology, the largest otoliths (asteriscus) were removed, dried in the oven, and gold coated for SEM observation. To examine the otolith daily growth increments, the otoliths were embedded in Epofix resin, ground, and polished along the transverse plan until the primordium of the otolith was exposed. The polished otolith was etched with $0.05 \mathrm{M} \mathrm{HCl}$ to reveal the daily growth increments, dried in the oven, and coated with a layer of gold for SEM observation.

\section{RESULTS \\ Immunocytochemical localization of $\mathrm{Na}^{+}-\mathrm{K}^{+}$-ATPase}

The cells showing the strongest $\mathrm{Na}^{+}-\mathrm{K}^{+}$-ATPase immunoreactivity (ir) appeared at the periphery of the sensory macula in both the lagena and the saccule (Fig. 1). For convenience, the term ionocytes was used to represent these $\mathrm{Na}^{+}-\mathrm{K}^{+}$-ATPase-ir cells thereafter for the sake of the specific function in ion transportation. Ionocytes have a well-developed tubular system, which is an $\mathrm{Na}^{+}-\mathrm{K}^{+}$ATPase-rich organelle (Pisam et al., 1998). Lagenar ionocytes are relatively large (10-30 $\mu \mathrm{m}$ in length) and have varied morphology, whereas saccular ionocytes are usually oval and relatively small (5-10 $\mu \mathrm{m}$ in length). Lagenar ionocytes were usually loosely inlaid in an arrangement of numerous transitional cells, and few ionocytes were connected to each other. In some individuals, the lagenar ionocytes were abundant and were densely connected by their cellular processes or pseudopods (Figs. 1, 2 ). The zebrafish used were of the same strain, but the size of fish was varied. Therefore, the variability in staining pattern of the ionocytes might be related to individual difference, such as inconsistency of growth and age. The saccular ionocytes usually formed several rows in tight arrangement at the posterior end of the sac. The sensory macula of the otolith organ consists of numerous hair cells, which are characterized by stereocilia at their apical surface. The red bundle demonstrated actin-rich stereocilia on each hair cell after being stained with TRITCconjugated phalloidin. Hair cells also showed strong $\mathrm{Na}^{+}$$\mathrm{K}^{+}$-ATPase-ir in the plasma membrane (Fig. 2f,i).

\section{Immunocytochemical localization of carbonic anhydrase}

The lagenar chamber demonstrated intense immunoreactivity for carbonic anhydrase (Fig. 2) in many cell types. These cells included ionocytes, transitional cells, and some squamous cell and granular cells between ionocytes and the sensory macula. Hair cells and supporting cells within the sensory macula also demonstrate intense immunoreactivity for carbonic anhydrase (Fig. 2). Immunofluoresent staining in these cells apparently had a cytoplasmic dis- 

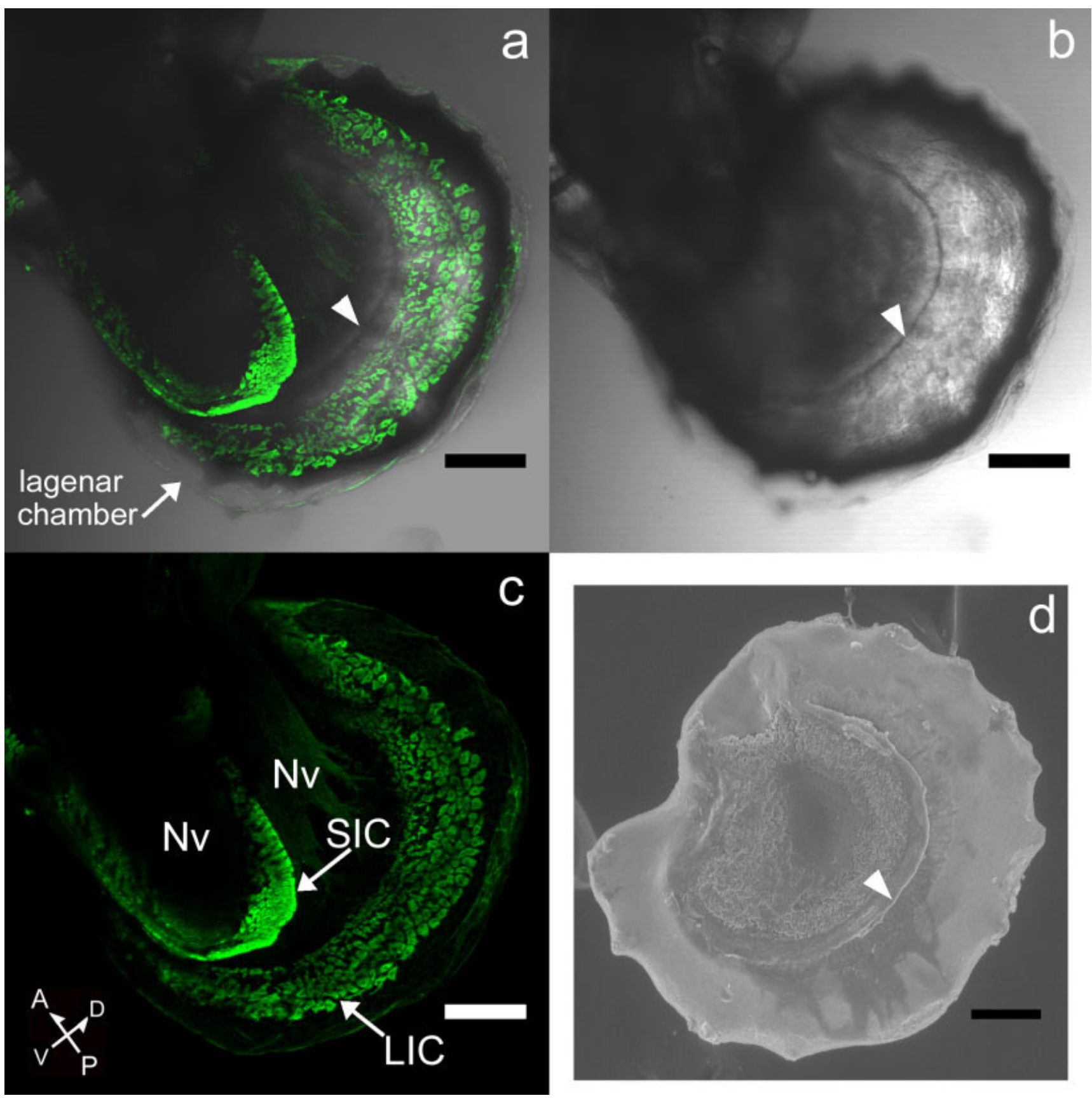

Fig. 1. Basolateral view of the confocal images (a-c) showing the immunocytochemical staining of $\mathrm{Na}^{+}-\mathrm{K}^{+}$-ATPase (green) in the intact saccular and lagenar chambers, which contain an otolith in each chamber. Saccular ionocytes (SIC) and lagenar ionocytes (LIC) show strong $\mathrm{Na}^{+}-\mathrm{K}^{+}$-ATPase staining and are distributed on the periphery of the sensory macula. The sensory maculae, covered by the hearing nerves $(\mathrm{Nv})$, are not visible in the basolateral view. Arrowheads

indicate the ridge-like thickened ring surrounding the sulcus of the otoilth. The proximal surface of same otolith is clearly illustrated in the SEM image (d) after removal of the otolith chamber. Sensory macula consisted of hair cells and supporting cells facing the rough sulcus, whereas ionocytes face the smooth otolith surface outside the sulcus. A, anterior; D, dorsal; $\mathrm{P}$, posterior; V, ventral. Scale bars $=100$ $\mu \mathrm{m}$.

tribution. However, ionocytes show relatively stronger staining of carbonic anhydrase in the plasma membrane than in the cytoplasm. It is worth noting that carbonic anhydrase is aggregated in the cytoplasm close to the apical membrane of hair cell and in some hair bundles

(Fig. 2d,g-i). The staining of carbonic anhydrase is not ubiquitous in all hair bundles, but usually appears in the hair bundles of the hair cells at the edge of the sensory macula (Fig. 2d,g-i). Immunohistochemical staining of carbonic anhydrase usually does not appear in the hair 

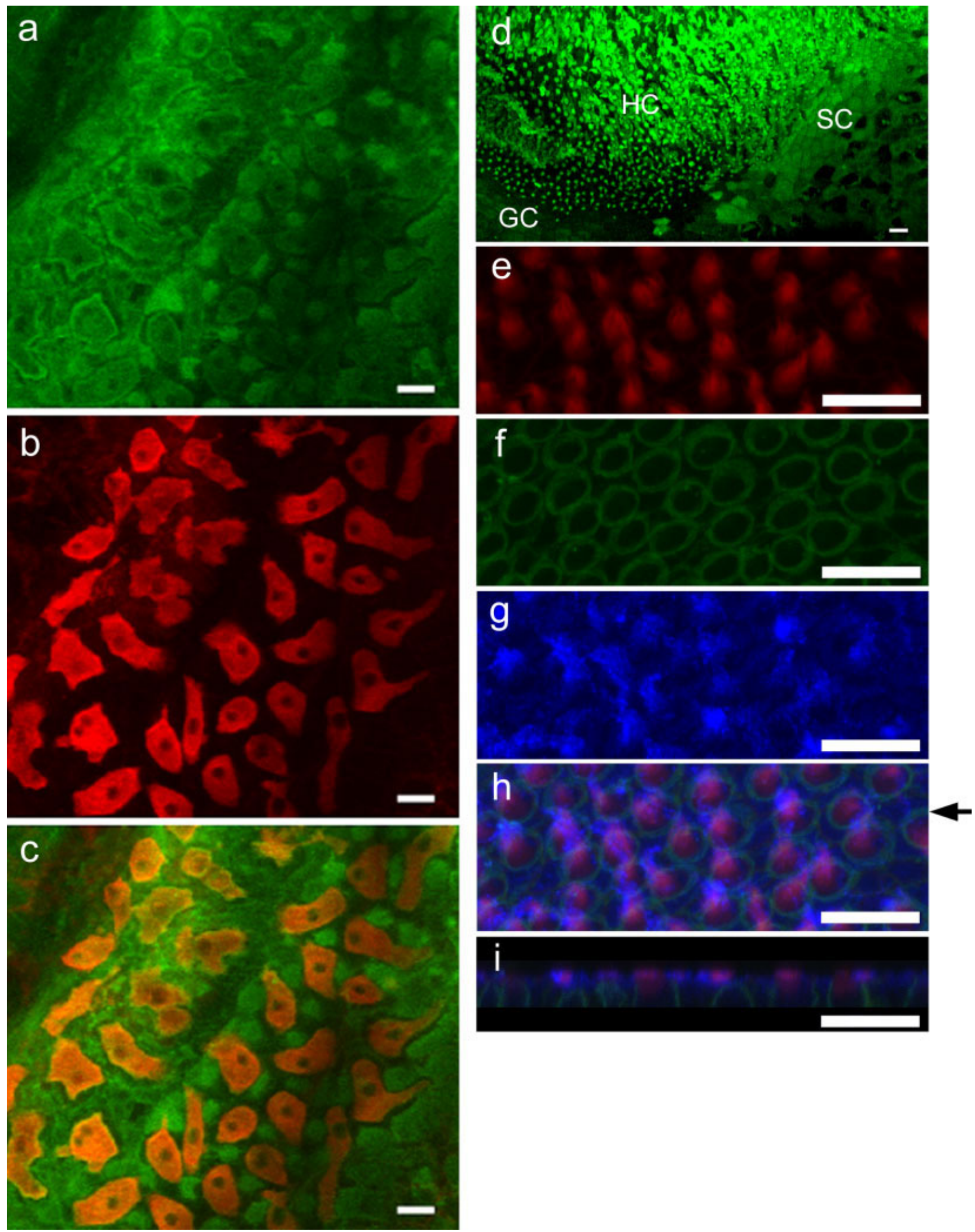

Fig. 2. Carbonic anhydrase (green, a) and $\mathrm{Na}^{+}-\mathrm{K}^{+}$-ATPase (red, b) double staining is shown in the lagenar chamber. $\mathrm{Na}^{+}-\mathrm{K}^{+}$-ATPase and carbonic anhydrase are colocolized in the ionocytes (orange, $\mathbf{c}$ ), which are surrounded by many transitional cells (green, a,c) that are carbonic anhydrase-immunoreactive but $\mathrm{Na}^{+}-\mathrm{K}^{+}$-ATPase-negative cells. d: Staining of carbonic anhydrase (green) in the cytoplasm of granular cells (GC), squamous cells (SC), hair cells (HC), and hair

bundles. e-i: Staining of carbonic anhydrase (blue, g-i), actin-rich hair bundles (red, e,h,i), and $\mathrm{Na}^{+}-\mathrm{K}^{+}$-ATPase (green, f,h,i) in the hair cells. i: $\mathrm{X}-\mathrm{Z}$ plane of $\mathrm{h}$ as indicated by the arrow shows the distribution of carbonic anhydrase close to the apical membrane (blue) and in the hair bundle (pink). $\mathrm{Na}^{+}-\mathrm{K}^{+}$-ATPase (green, f,h,i) is distributed in the plasma membrane of hair cells. Scale bars $=10 \mu \mathrm{m}$ 

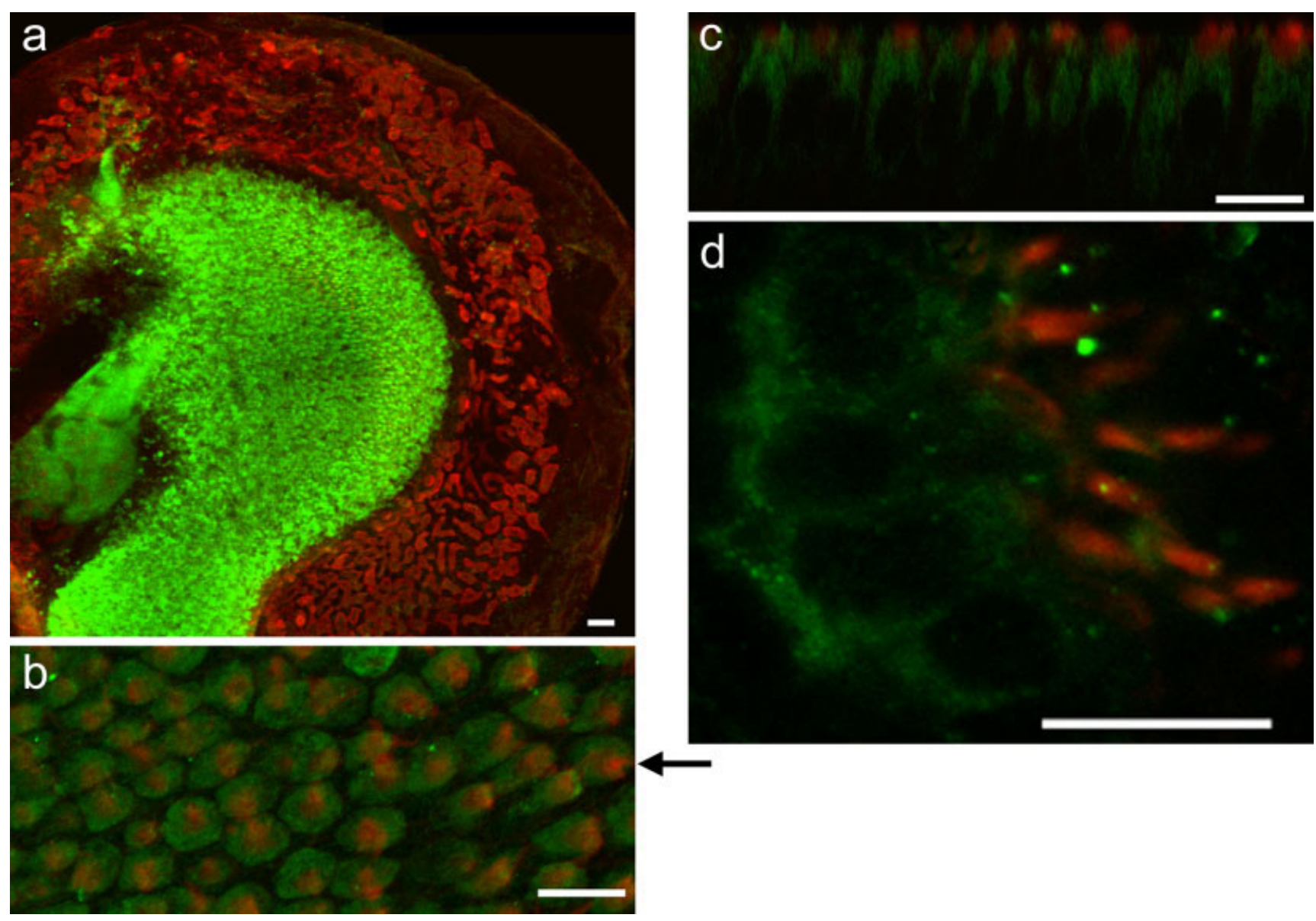

Fig. 3. Immunocytochemical staining of $\mathrm{Na}^{+}-\mathrm{K}^{+}$-ATPase and $\mathrm{H}^{+}$ATPase in the lagenar chamber. a: Prominent staining of $\mathrm{H}^{+}$-ATPase (green) in the sensory macula, surrounded by several rows of ionocytes, which show intense staining of $\mathrm{Na}^{+}-\mathrm{K}^{+}$-ATPase (red). b: $\mathrm{H}^{+}-$ ATPase (green) is densely distributed in the apical membrane of hair cells and surrounds the hair bundle, which is stained by phalloidin

conjugated with TRITC (red). c: X-Z plane of $b$ as indicated by the arrow. Red indicates the hair bundle, and green indicates the $\mathrm{H}^{+}$. ATPase. d: Staining of $\mathrm{H}^{+}$-ATPase (green) in the hair cells, which are characterized by the hair bundle stained by phalloidin-conjugated with TRITC (red) in zebrafish larva at 3 days postfertilization. Scale bars $=100 \mu \mathrm{m}$ in $\mathrm{a} ; 10 \mu \mathrm{m}$ in b-d.

bundle of the hair cells distributed at the inner area of the sensory macula. This may indicate a heterogeneity and developmental difference among hair cells, as was found by Bang et al. (2001).

\section{Immunocytochemical localization of $\mathbf{H}^{+}$-ATPase}

The $\mathrm{H}^{+}$-ATPase-ir cells were found only in the apical side of the labyrinth within the sensory macula (Fig. 3a). Actin-rich hair bundles bound by phalloidin always appeared in these $\mathrm{H}^{+}$-ATPase-ir cells. This indicated that $\mathrm{H}^{+}$-ATPase was located in the hair cells (Fig. 3b), not in the supporting cells. The hair cells showed the strongest staining of $\mathrm{H}^{+}$-ATPase in the apical membrane surrounding the hair bundle (Fig. 3b,c). There was no $\mathrm{H}^{+}$-ATPase immunoreactivity found in other cell types, suggesting that $\mathrm{H}^{+}$-ATPase was specifically expressed in the hair cells. The hair cells showed differential $\mathrm{H}^{+}$-ATPase immunostaining, with the strongest staining at the distinctive patch near the anterior sensory macula and at the edge of the sensory macula. The weakest staining of $\mathrm{H}^{+}$-ATPase appeared at the central area of the sensory macula (Fig. 3a). $\mathrm{H}^{+}$-ATPase was

expressed in the hair cells of zebrafish larva at least as early as 3 day postfertilization (Fig. 3d).

\section{Control experiments}

Negative control of the whole-mount sample obtained by omitting the primary antibody from the staining protocol demonstrated absence of staining on the labyrinth epithelium (data not shown). This indicated that the secondary antibodies used exhibited minimal cross-reactivity with the labyrinth tissues of zebrafish.

\section{Immunoblotting}

Labyrinth homogenate was subjected to immunoblotting to identify the presence of $\mathrm{Na}^{+}-\mathrm{K}^{+}$-ATPase, carbonic anhydrase, and $\mathrm{H}^{+}$-ATPase in the saccular epithelial cells. The immunoblot of $\mathrm{Na}^{+}-\mathrm{K}^{+}$-ATPase, carbonic anhydrase, and $\mathrm{H}^{+}$-ATPase showed clear bands at molecular masses of approximately 110, 30, and $75 \mathrm{kDa}$, respectively (Fig. 4).

\section{Proton activities ( $\mathbf{p H})$ at hair cells}

To evaluate proton secretion from the hair cell, we use $\mathrm{H}^{+}$-selective microelectrodes to measure $\mathrm{H}^{+}$activity $(\mathrm{pH})$ 


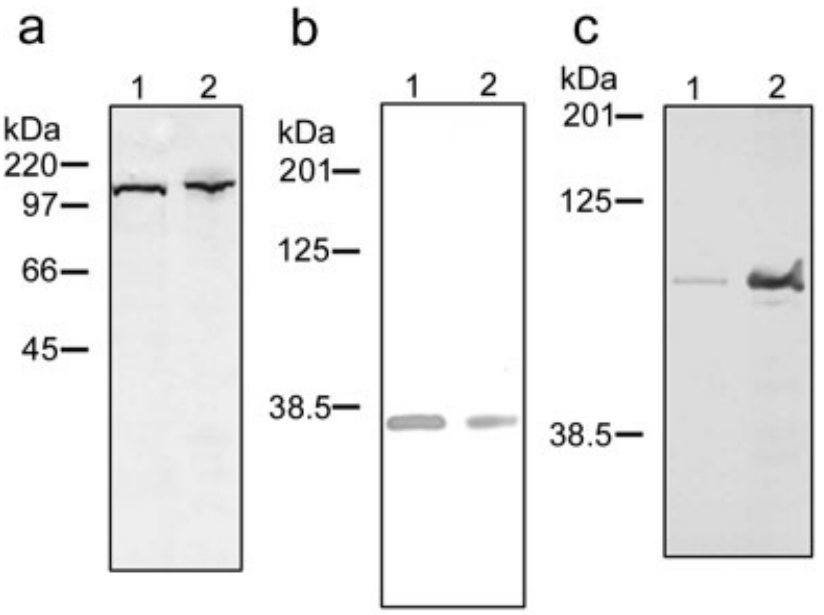

Fig. 4. Immunoblotting of $\mathrm{Na}^{+}-\mathrm{K}^{+}$-ATPase (a), carbonic anhydrase (b), and $\mathrm{H}^{+}$-ATPase (c) extracted from the labyrinths of zebrafish (lane 1) and rat kidney as positive control (lane 2). The antibody against $\mathrm{Na}^{+}-\mathrm{K}^{+}$-ATPase, carbonic anhydrase, and $\mathrm{H}^{+}$-ATPase recognized a clear band at molecular masses of approximately 110, 30, and $75 \mathrm{kDa}$, respectively. Positions of the molecular markers $(\mathrm{kDa})$ are indicated at left.

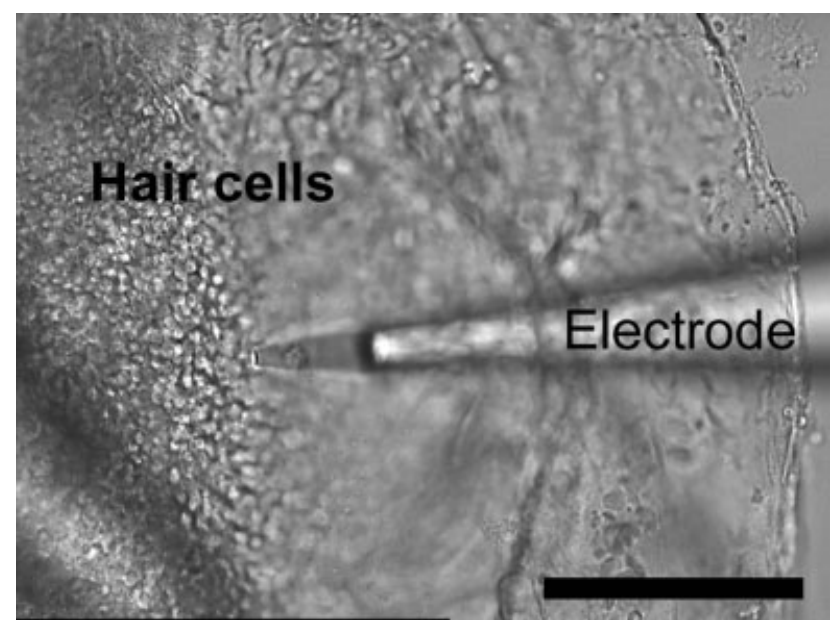

Fig. 5. Measurement of proton activity at the apical side of hair cells by the $\mathrm{H}^{+}$-selective microelectrode technique. Scale bar $=100$ $\mu \mathrm{m}$.

at the surface of hair cells. The extracted lagena was immersed in Ringer solution, and otolith was removed to expose the hair cells. The hair cells were easily identified from their unique morphology and distribution at a magnification of $\times 400$ under a DIC microscope (Fig. 5). $\mathrm{H}^{+}$ activity was immediately measured by the $\mathrm{H}^{+}$-selective microelectrode technique. When the electrode moved very close to the hair cells (about $2-4 \mu \mathrm{m}$ above hair cells), the measured $\mathrm{pH}$ value dropped from approximately 8 in the background (more than $500 \mu \mathrm{m}$ away from the sample) to approximately 7.6 near the hair cell (Fig. 6). The strongest proton activity was detected near the apical membrane of hair cells, and proton activity gradually decreased when the electrode was moved away from the hair cells. The

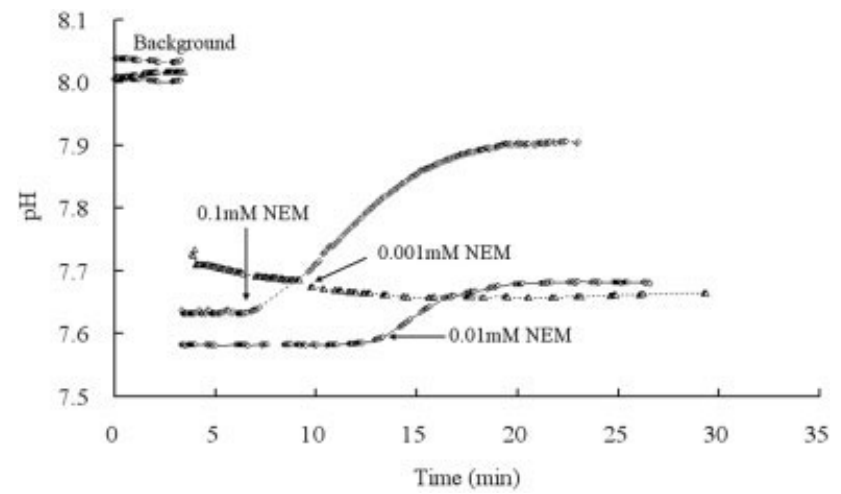

Fig. 6. $\mathrm{H}^{+}$activity $(\mathrm{pH})$ at the apical side of hair cells. During the experiment, the electrode was moved from a background region (more than $500 \mu \mathrm{m}$ away from the tissue) to the apical side of hair cells (about 2-4 $\mu \mathrm{m}$ above hair cells). The measured $\mathrm{pH}$ value dropped from approximately 8 in the background to approximately 7.6 near the hair cell. The arrows indicated the time at which $\mathrm{N}$-ethylmaleimide (NEM) was added. NEM at 0.1 and $0.01 \mathrm{mM}$ can disrupt the $\mathrm{H}^{+}$gradient, but $0.001 \mathrm{mM}$ NEM or Ringer solution alone (data not shown) has no influence on proton secretion.

inhibitory effect of proton secretion was evaluated by using different concentrations of NEM. After addition of the $\mathrm{H}^{+}$-ATPase inhibitor $\mathrm{NEM}$ at 0.1 and $0.01 \mathrm{mM}$ to the hair cells, the $\mathrm{pH}$ value quickly increased to more than 7.9 and approximately 7.7, respectively (Fig. 6). However, 0.001 $\mathrm{mM}$ NEM or Ringer solution alone has no influence on $\mathrm{pH}$ value. Vacuolar $\mathrm{H}^{+}$-ATPase is sensitive to low concentrations of NEM. The complete inhibition of proton secretion from hair cells by applying $0.1 \mathrm{mM}$ NEM and partial inhibition by $0.01 \mathrm{mM} \mathrm{NEM}$ indicates that the proton gradient generated by the hair cells is mediated by the vacuolar $\mathrm{H}^{+}$-ATPase. In addition, the dose-dependent inhibitory effect of different concentrations of NEM suggests that the inhibition of $\mathrm{H}^{+}$-ATPase by NEM is not a pharmacological effect.

\section{Otolith morphology}

The otolith (asteriscus) of zebrafish is an ovate structure with regular wave-like curves on the margin. The sulcus in the proximal surface forms an oval groove opening to the anterior margin (Fig. 7a). The convex distal surface of the otolith has no distinctive features (Fig. 7b). The grooved sulcus is very similar in shape to the pattern of hair cell distribution in the sensory macula (Fig. 3a). Furthermore, the sulcus surface is smooth at the central area and becomes rough at the edge. High magnification shows many cracks within the small granular $\mathrm{CaCO}_{3}$ structure at the edge of the sulcus. Many granular structures are connected and fused to form larger ones toward the center of the sulcus (Fig. 7c), and a ridge-like thickened ring surrounds the sulcus, indicating rapid $\mathrm{CaCO}_{3}$ deposition. Outside the sulcus, the otolith surface is very smooth, and no cracks or granular structure are observed. This area outside the sulcus of the otolith faces the otolith chamber where ionocytes are distributed. The daily growth increments were faster dorsoventrally than distally-proximally and were merged in the proximal surface of the otolith from first ring formation (Fig. 7d). This indicates that $\mathrm{CaCO}_{3}$ deposition is inhibited in the proximal surface of the otolith beginning at the early stage of the fish. 

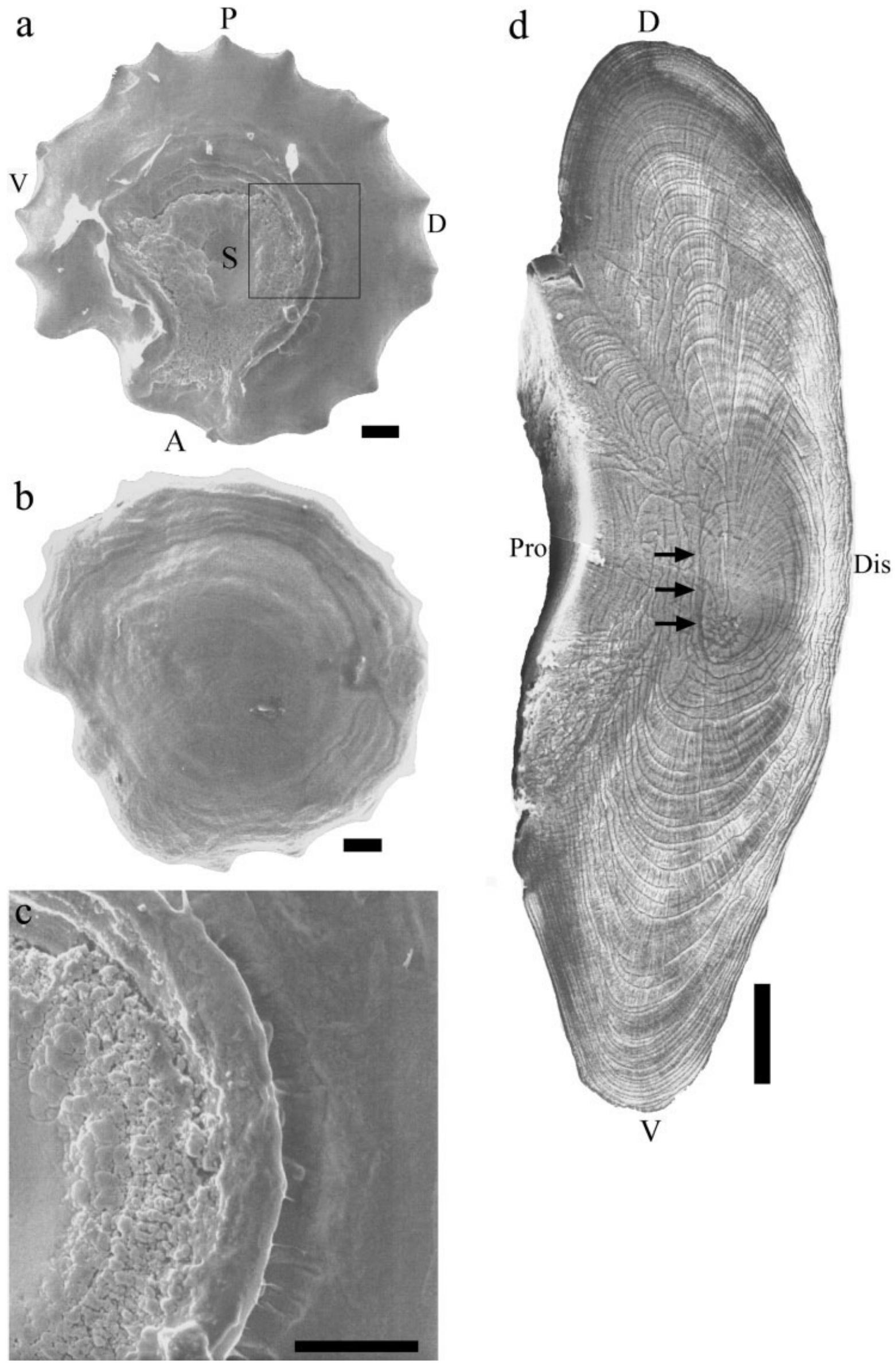

Fig. 7. 


\section{DISCUSSION Specificity of the primary antibodies}

The protein molecular weights evaluated by Western blot confirmed the specificity of the antibodies to $\mathrm{Na}^{+}-\mathrm{K}^{+}$ATPase, carbonic anhydrase, and $\mathrm{H}^{+}$-ATPase in the labyrinth of zebrafish. The molecular weights of $\mathrm{Na}^{+}-\mathrm{K}^{+}$ATPase, carbonic anhydrase, and $\mathrm{H}^{+}$-ATPase were approximately 110,30 , and $75 \mathrm{kDa}$, respectively. The molecular weight of each protein is consistent with data from other species (Sender et al., 1999; Katoh et al., 2003). The molecular sizes of approximately 110,30 , and $75 \mathrm{kDa}$ also agree with the expected size of the zebrafish $\mathrm{Na}^{+}-\mathrm{K}^{+}$. ATPase $\alpha$-subunit (Rajarao et al., 2001), carbonic anhydrase II (Peterson et al., 1997), and $\mathrm{H}^{+}$-ATPase $\alpha$-subunit (Gene Bank accession No. BC055130). Accordingly, the Western blot supports the reliability of the immunoreactivity of carbonic anhydrase, $\mathrm{Na}^{+}-\mathrm{K}^{+}$-ATPase, and $\mathrm{H}^{+}$ATPase to each primary antibody.

\section{Function of ionocytes}

The staining of $\mathrm{Na}^{+}-\mathrm{K}^{+}$-ATPase, $\mathrm{H}^{+}$-ATPase, and carbonic anhydrase in ionocytes and hair cells suggests their participation in endolymphatic $\mathrm{pH}$ regulation and ion transportation. $\mathrm{Na}^{+}-\mathrm{K}^{+}$-ATPase $\alpha$ - and $\beta$-subunit genes were abundantly and differentially expressed throughout the otic epithelium in the early developmental stage (1-5 dpf) of zebrafish (Blasiole et al., 2003). This indicates that different $\mathrm{Na}^{+}-\mathrm{K}^{+}$-ATPase subunits are involved in the formation of inner ear at the early developmental stage as well as the ion regulation of endolymph at the later stages. The cellular and molecular mechanisms of zebrafish inner ear development were described in detail by Haddon and Lewis (1996) and Whitfield et al. (2002). However, the expression patterns of carbonic anhydrase and $\mathrm{H}^{+}$. ATPase genes in fish inner ear are still unclear. Carbonic anhydrase in the ionocytes hydrolyzes $\mathrm{CO}_{2}$ and generates $\mathrm{HCO}_{3}{ }^{-}$and $\mathrm{H}^{+}$. $\mathrm{HCO}_{3}{ }^{-}$is presumably secreted into the endolymph by a $\mathrm{Cl}^{-} / \mathrm{HCO}_{3}{ }^{-}$exchanger and combines with $\mathrm{Ca}^{2+}$ to form $\mathrm{CaCO}_{3}$ aragonite crystals. $\mathrm{Na}^{+}-\mathrm{K}^{+}$-ATPase on the basolateral membrane creates a sodium gradient that drives the $\mathrm{Na}^{+} / \mathrm{H}^{+}$exchanger to pump $\mathrm{H}^{+}$out of the cell (Payan et al., 1997; Tohse and Mugiya, 2001). The formation of a ring of ionocytes around the sensory macula is consistent with the observations of Mayer-Gostan et al. (1997). Their distribution coincidentally faces the proximal convex surface of the otolith. This is the area where $\mathrm{CaCO}_{3}$ biomineralizes rapidly. This collective evidence indicates that ionocytes are the cells responsible for the transepithial transport of $\mathrm{HCO}_{3}{ }^{-}$and subsequent otolith growth. The transitional cells are also densely interspersed among the ionocytes. This arrangement differs from that in mammals, whose transitional cells occur between the sensory epithelium and the dark-cell area func-

Fig. 7. Topology and microstructure of the zebrafish asteriscus. SEM photos showing the rough and granular structure in the otolith sulcus (a) and the smooth surface in other areas of the otolith $(\mathbf{b}, \mathbf{c})$ Higher magnification of the boxed area in a is shown in c. d: Ground and etched otolith, demonstrating rapid daily growth along the dorsal-ventral axis and retarded growth along the distal-proximal axis. Arrows indicate the merge of the daily growth increments in the proximal surface. A, anterior; D, dorsal; Dis, distal; P, posterior; Pro, proximal; S, sulcus; V, ventral. Scale bars $=50 \mu \mathrm{m}$. tionally equivalent to teleostean ionocytes (Hunter-Duvar and Hinojosa 1984). However, the prominent staining of carbonic anhydrase in the transitional cells is consistent with that in the mammalian inner ear (Hsu, 1991). Davis et al. (1995) and Takagi (2000) have pointed out that transitional cells are responsible for the production of otolith protein matrix. The close association of transitional cells and ionocytes results in the secretion of organic protein matrix and inorganic ions $\left(\mathrm{HCO}_{3}{ }^{-}\right)$in the same area and produces rapid $\mathrm{CaCO}_{3}$ biomineralization outside the sulcus. Both ionocytes and transitional cells are found only in the proximal side of the otolith chamber. The distal side of the otolith is surrounded only by the squamous cells and has the slowest growth (Fig. 7d). Squamous cells are unlikely to provide calcium, bicarbonic ions, or organic matrix, insofar as ion transportation and protein secretion are not found in these cells. The only supply of calcium, bicarbonic ions, and organic matrix is probably from diffusion from the proximal side to the distal side. The diffusion is a passive and slow process that may account this slow growth in the distal side of the otolith.

\section{Function of $\mathbf{H}^{+}$-ATPase in hair cells}

Payan et al. (1999) observed low $\mathrm{pH}$ values of the endolymph around the sensory macula and hypothesized that the concentrated $\mathrm{H}^{+}$around the sensory macula had diffused from its production site, where $\mathrm{CaCO}_{3}$ was deposited quickly. This is very hypothetical, in that ionic diffusion typically occurs from high to low concentration. Proton-secreting $\mathrm{H}^{+}$-ATPase is widely found in various tissues, e.g., kidney, gill, skin, and osteoclasts (Brown and Breton, 1996). $\mathrm{H}^{+}$-ATPase in the osteoclasts is involved in bone remodelling by acidifying the osteoclasts-bony interface (Blair et al., 1989; Vaananen et al., 1990). The proton secretion by the hair cells causes $\mathrm{pH}$ values of the endolymph to decrease by approximately 0.4 units within the sensory macula (Fig. 6). The neutralized microenvironment facing the sensory macula does not favor $\mathrm{CaCO}_{3}$ formation and thus causes slow otolith growth in the sulcus. There are numerous cracks and granular $\mathrm{CaCO}_{3}$ structures on the sulcus that coincidently face the hair cells, which has the strongest $\mathrm{H}^{+}$-ATPase immunostaining (Figs. 3, 7). There was relatively less staining of the hair cells facing the smooth central surface of the sulcus. These results indicate that $\mathrm{H}^{+}$-ATPase in the apical membrane of hair cells functions to secrete $\mathrm{H}^{+}$into endolymph and to retard $\mathrm{CaCO}_{3}$ biomineralization or even dissolve the partial $\mathrm{CaCO}_{3}$ within the sensory macula. Carbonic anhydrase, which shows prominent staining in the cytoplasm close to the apical membrane of hair cells and in the hair bundle, can provide the $\mathrm{H}^{+}$source by catalyzing $\mathrm{H}_{2} \mathrm{O}$ and $\mathrm{CO}_{2}$ (Fig. 2). The apical proton secretion results in the generation of $\mathrm{HCO}_{3}{ }^{-}$inside the hair cell, which can exit from the basolateral membrane through a $\mathrm{Cl}^{-} / \mathrm{HCO}_{3}{ }^{-} \mathrm{ex}-$ changer. Chloride then exits via a basolateral chloride channel as described for the "A-type" intercalated cell of the kidney collecting tubule (Gluck and Nelson, 1992). Figure 8 depicts the relative position between otolith and different epithelial cells. The ion transporters that may be involved in the $\mathrm{pH}$ regulation of the endolymph are also illustrated in the hair cell and the ionocyte (Fig. 8b).

The teleostean hair cell is virtually the same as that found in the inner ears of other vertebrates (Chang et al., 1992). Stankovic et al. (1997) also demonstrated the apical 

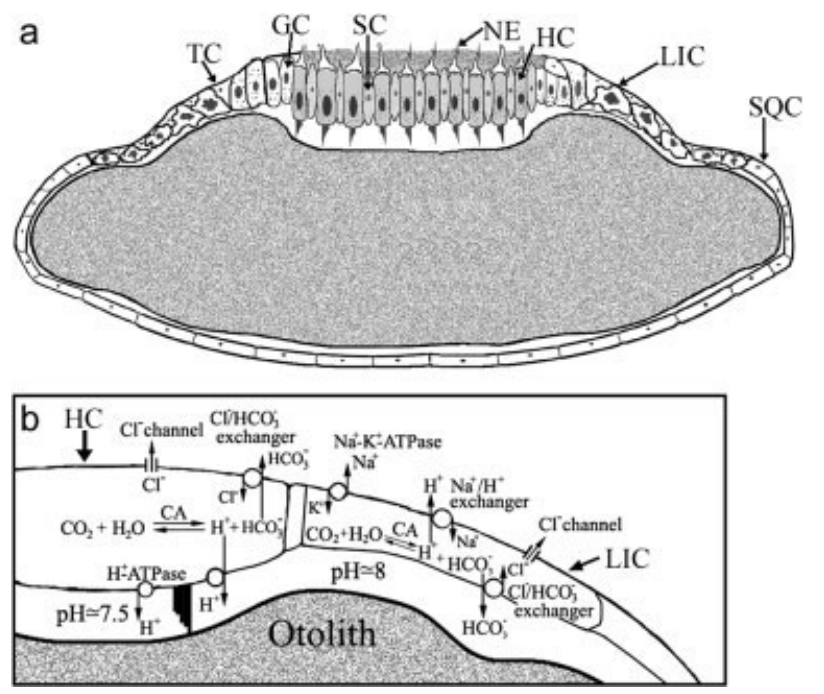

Fig. 8. a: Schematic diagram of different epithelial cell types in the lagenar chamber of zebrafish and their positions relative to the otolith. b: Hypothetical model demonstrates the ion transporters and channels, which may participate in regulating endolymphic $\mathrm{pH}$ value. CA, carbonic anhydrase; GC, granular cell; HC, hair cell; LIC, lagenar ionocytes; NE, nerve ending; SC, supporting cell; SQC, squamous cell; TC, transitional cell. These diagrams are not drawn to scale.

distribution of $\mathrm{H}^{+}$-ATPase in strial marginal cells in mammalian cochlea. Hair cells of the utricle, the saccule, and the cristae ampullaris also expressed $\mathrm{H}^{+}$-ATPase and the $\mathrm{Cl}^{-} / \mathrm{HCO}_{3}{ }^{-}$exchanger. Stankovic et al. (1997) suggested that these cells were involved in the regulation of endolymphic $\mathrm{pH}$ within normal values. The hair bundles of mammalian hair cells are embedded and protected by the otoconial membrane. However, the hair bundles of teleostean hair cells are exposed in the endolymph and are in direct contact with a fast-growing otolith. A protective device must be adopted to maintain a proper working distance between the fish otolith and the hair cells. Otherwise, the quickly accreting otolith would crush the hair cells and eventually cause dysfunction of the receptor organs. The proton-secreting $\mathrm{H}^{+}$-ATPase on the apical surface of hair cells evidently neutralizes or acidifies the microenvironment and retards or dissolves $\mathrm{CaCO}_{3}$ deposition. Hair cells are developed in the $24 \mathrm{hpf}$ embryo stage, before otolith formation (Whitfield et al. 2002). We observed that $\mathrm{H}^{+}$-ATPase is expressed in the hair cell of zebrafish at 3 day postfertilization. Furthermore, otolith formation is also inhibited on the proximal surface starting from the formation of the first daily growth increment. All the evidence indicates that $\mathrm{H}^{+}$-ATPase plays an important role in protecting hair cells starting from the early developing stage.

\section{Hair cells and ionocytes control otolith morphology}

From immunoblotting, immunocytochemical staining, electrophysiological evidence, and observation of otolith topology and microstructure, the hair cells in teleostean otolith organs were determined to have a vacuolar $\mathrm{H}^{+}$ATPase in their apical membrane. The close association between mechanosensory hair cells and the accreting oto- lith can be maintained by the proton-secreting $\mathrm{H}^{+}$ATPase, which neutralizes or acidifies the microenvironment to dissolve $\mathrm{CaCO}_{3}$ or retard otolith growth on the surface facing the sensory macula. The ionocytes surrounding the sensory macula secrete quantities of $\mathrm{HCO}_{3}^{-}$ to sustain otolith growth. The unique distribution of ionocytes also acts as a barrier to maintain the alkaline endolymph outside the sensory macula. The endolymphic microenvironment within the sensory macula does not favor otolith growth whereas ionocytes promote otolith growth outside the sulcus, resulting in a sculptured groove along the proximal medial face of all otoliths.

\section{ACKNOWLEDGMENTS}

We extend our full gratitude to S.C. Chen and T.L. Lin for assistance with the experiment and to B. Jessop for suggestions on the article.

\section{LITERATURE CITED}

Bang PI, Sewell WF, Malicki JJ. 2001. Morphology and cell type heterogeneities of the inner ear epithelia in adult and juvenile zebrafish (Danio rerio). J Comp Neurol 438:173-190.

Blair HC, Teitelbaum SL, Ghiselli R, Gluck S. 1989. Osteoclastic bone resorption by a polarized vacuolar proton pump. Science 245:855-857.

Blasiole B, Degrave A, Canfield V, Boehmler W, Thisse C, Thisse B, Mohideen MPK, Levenson R. 2003. Differential expression of $\mathrm{Na}$, K-ATPase- $\alpha$ and $-\beta$ subunit genes in the developing zebrafish inner ear. Dev Dyn 228:386-392.

Brown D, Breton S. 1996. Mitochondria-rich, proton-secreting epithelial cells. J Exp Biol 199:2345-2358.

Campana SE, Neilson JD. 1985. Microstructure of fish otoliths. Can J Fish Aquat Sci 42:1014-1032.

Chang JSY, Popper AN, Saidel WM. 1992. Heterogeneity of sensory hair cells in a fish ear. J Comp Neurol 324:621-640.

Davis JG, Oberholtzer JC, Burns FR, Greene MI. 1995. Molecular cloning and characterization of an inner ear-specific structural protein. Science 267:1031-1034.

Dunkelberger DA, Dean JM, Watabe N. 1980. The ultrastructure of the otolithic membrane and otolith in the juvenile mummichog, Fundulus heteroclitus. J Morphol 163:367-377.

Gluck S, Nelson R. 1992. The role of the V-ATPase in renal epithelial $\mathrm{H}^{+}$ transport. J Exp Biol 172:205-218.

Haddon C, Lewis J. 1996. Early ear development in the embryo of the zebrafish, Danio rerio. J Comp Neurol 365:113-128.

Hsu CJ. 1991. Ultrastructural study of cytochemical localization of carbonic anhydrase in the inner ear. Acta Otolaryngol 111:75-84.

Hudspeth AJ. 1989. How the ear's works work. Nature 341:397-404.

Hunter-Duvar IM, Hinojosa R. 1984. Vestibule: sensory epithelia. In: Friedmann I, Ballantyne J, editors. Ultrastructural atlas of the inner ear. London: Butterworths. p 211-244.

Katoh F, Hyodo S, Kaneko T. 2003. Vacuolar-type proton pump in the basolateral plasma membrane energizes ion uptake in branchial mitochondria-rich cells of killifish Fundulus heteroclitus, adapted to a low ion environment. J Exp Biol 206:793-803.

Lim DJ. 1984. The development and structure of the otoconia. In: Friedmann I, Ballantyne J, editors. Ultrastructural atlas of the inner ear. London: Butterworths. p 245-269.

Mayer-Gostan N, Kossmann H, Watrin A, Payan P, Boeuf G. 1997. Distribution of ionocytes in the saccular epithelium of the inner ear of two teleosts Oncorhynchus mykiss and Scophthalmus maximus. Cell Tissue Res 289:53-61.

Pannella G. 1971. Fish otoliths: daily growth layers and periodical patterns. Science 173:1124-1127.

Payan P, Kossmann H, Watrin A, Mayer-Gostan N, Boeuf G. 1997. Ionic composition of endolymph in teleosts: origin and importance of endolymph alkalinity. J Exp Biol 200:1905-1912.

Payan P, Edeyer A, De Pontual H, Borelli G, Boeuf G, Mayer-Gostan N. 1999. Chemical composition of saccular endolymph and otolith in fish 
inner ear: lack of spatial uniformity. Am J Physiol Regul Integr Comp Physiol 46:123-131.

Peterson RE, Tu CK, Linser PJ. 1997. Isolation and characterization of a carbonic anhydrase homologue from the zebrafish (Danio rerio). J Mol Evol 44:432-439.

Pisam M, Payan P, LeMoal C, Edeyer A, Boeuf G, Mayer-Gostan N. 1998. Ultrastructural study of the saccular epithelium of the inner ear of two teleosts, Oncorhynchus mykiss and Psetta maxima. Cell Tissue Res 294:261-270.

Rajarao SJR, Canfield VA, Mohideen MPK, Yan YL, Postlethwait JH, Cheng KC Levenson R. 2001. The repertoire of Na, K-ATPase $\alpha$ and $\beta$ subunit genes expressed in the zebrafish, Danio rerio. Genome Res 11:1211-1220.

Schellart NAM, Wubbels RJ. 1998. The auditory and mechanosensory lateral line system. In: Evans DH, editor. The physiology of fishes. New York: Academic Press. p 283-312.

Sender S, Bottcher K, Cetin Y, Gross G. 1999. Carbonic anhydrase in the gills of seawater- and freshwater-acclimated flounders Platicchthys flesus: purification, characterization, and immunohistochemical localization. J Histochem Cytochem 47:43-50.

Stankovic KM, Brown D, Alper SL, Adams JC. 1997. Localization of $\mathrm{pH}$ regulating proteins $\mathrm{H}^{+}$-ATPase and $\mathrm{Cl}^{-} / \mathrm{HCO}_{3}^{-}$exchanger in the guinea pig inner ear. Hear Res 114:21-34.

Takagi Y. 2000. Ultrastructural immunolocalization of the otolith watersoluble-matrix in the inner ear of rainbow trout just-hatched fry. Fish Sci 66:71-77.

Tohse H, Mugiya Y. 2001. Effects of enzyme and anion transport inhibitors on in vitro incorporation of inorganic carbon and calcium into endolymph and otoliths in salmon Oncorhynchus masou. Comp Biochem Physiol 128A:177-184.

Vaananen HK, Karhukorpi EK, Sundquist K, Wallmark B, Roininen I, Hentunen T Tuukkanen J, Lakkakorpi P. 1990. Evidence for the presence of a proton pump of the vacuolar $\mathrm{H}^{+}$-ATPase type in the ruffled borders of osteoclasts. J Cell Biol 111:1305-1311.

Whitfield TT, Riley BB, Chiang MY, Phillips B. 2002. Development of the zebrafish inner ear. Dev Dyn 223:427-458. 